\title{
IKAN YANG BERUAYA DI DAERAH MANGROVE PANTAI TASIK RIA
}

\author{
Otinus Lokbere, F.B. Boneka, C.A. Sinjal, Billy Th. Wagey, Medy Ompi, R.O.S.E. \\ Mantiri
}

Fakultas Perikanan \& IImu Kelautan, Universitas Sam Ratulangi, Manado 95115 Email: otinuslokbere4@gmail.com

\begin{abstract}
This study is intended to find out the fish that are cultured into the mangrove area of Tasik Ria beach, Mokupa, Minahasa Regency. Fish is obtained through gill jarring at high tide. The fish that were identified were Archamia fucata, Lutjanus fulvus, Lutjanus eherenbergii, Lethrinus ornatus, Scolopsis lineate, Sargocentron diadema, Epinephelus merra and Scorpaenopsis oxycephala. The fish are generally carnivorous, and are nocturnal.

Key words: Tasik Ria Beach, the fishes, carnivorous, mangroves

Abstrak

Studi ini dimaksudkan untuk mengetahui ikan yang beruaya ke daerah mangrove pantai Tasik Ria, Mokupa Kabupaten Minahasa. Ikan diperoleh melalui jarring insang pada saat air pasang. Ikan berhasil diientifikasi terdiri dari Archamia fucata, Lutjanus fulvus, Lutjanus eherenbergii, Lethrinus ornatus, Scolopsis lineate, Sargocentron diadema, Epinephelus merra dan Scorpaenopsis oxycephala. Ikan-ikan tersebut umumnya karnivor, dan bersifat nocturnal.
\end{abstract}

Kata kunci : Pantai Tasik Ria, ikan-ikan, carnivore, hutan bakau

\section{PENDAHULUAN}

Daerah mangrove umumnya berada di muara sungai, dan merupakan akhir dari partikel-partikel organik yang terbawa dari hulu. Mangrove menjadi bagian dari ekosistem pantai yang berperan sebagai daerah siklus unsur hara atau nutrient, dan penopang kehidupan berbagai biota akuatik yang berasosiasi di dalamnya (Boneka, 2013, 1994; Schaduw, 2015; Pramudji, 2008). Selain itu, mangrove berfungsi juga sebagai tempat pemijahan (spawning ground) dan daerah asuhan (nusery ground) dan tempat mencari makan (feeding ground) bagi sebagian biota akuatik, bahkan sebagai tempat bersarang dan istirahat sejumlah burung dan terrestrial vertebrata lainnya.

Study sejenis dilakukan oleh Suyoto et al (2019) yang melaporkan kehadiran berbagai jenis ikan dengan beragam kelompok makan (feeding categories) secara regular pada saat air pasang di daerah mangrove, Daerah Perlindungan Laut (DPL) Sulawesi Utara, yang didominasi oleh ikan-ikan karnivor. Penelitian ini bertujuan untuk untuk mengidentifikasi jenis-jenis ikan yang beruaya pada saat air pasang baik pada waktu pagi maupun pada malam hari ke daerah mangrove pantai Tasik Ria dan mengelompokkannya berdasarkan kategori makan.

\section{METODE PENELITIAN}

Lokasi. Pengumpulan ikan sampel dilaksanakan di pantai Tasik Ria, Mokupa, Kabupaten Minahasa, terletak sekitar 10 $\mathrm{km}$ dari Kota Manado. Ekosistem pantai di kawasan wisata ini terpelihara dengan baik, ditandai dengan mangrove tumbuh lebat. Kegiatan berlangsung selama 3 hari, yaitu pada tanggal 21-23 Maret 2019. Amplitudo pasang pada bulan purnama mencapai $\pm 2 \mathrm{~m}$. Daerah mangrove di pantai Tasik Ria menjadi bagian dari wilayah intertidal yang lebarnya lebih dari $100 \mathrm{~m}$ pada saat surut terendah. Untuk identifikasi ikan, analisis data dan penulisan laporan dilakukan di laboratorium Biologi Kelautan, Fakultas Perikanan dan IImu Kelautan, Universitas Sam Ratulangi Manado.

Prosedur di lapangan. Pengumpulan sampel ikan dilakukan melalui tahapan sebagai berikut: (1) survey pendahuluan di lokasi penelitian dan mewawancarai nelayan sekitar; (2) mempersiapkan alat tangkap berupa jaring insang (gill net) dan perahu (pelang); (3) kegiatan pada fase 
bulan purnama, air pasang mencapai maksimum; (4) jaring dengan panjang 25 $\mathrm{m}$, lebar $1 \mathrm{~m}$, mata jarring 3,5 cm diletakan di bagian luar daerah mangrove pada saat pasang, sekitar jam 05:00 dan 18:00 wita; (5) Pada saat air mulai surut, ikan-ikan mulai meninggalkan daerah mangrove menuju ke arah laut, dan akhirnya ikan terjerat di jaring; (6) ikan terjaring dilepaskan dari jarring, kemudian dimasukan kedalam box pendingin ; (7) Sampel ikan dibawa ke Laboratorium Biologi Kelautan, FPIK Unsrat.

Kegiatan di Laboratorium. Kegiatan di laboratorium dilaksanakan dengan urutan: (1) mengidentifikasi ikan sampel; (2) ikan dikelompokkan berdasarkan kesamaan morfologi, dan diidentifikasi dan difoto; (3) ikan sampel diukur panjang total dan panjang standard dengan menggunakan mistar, ketelitian $0,1 \mathrm{~cm}$; panjang total diukur dari ujung bagian kepala terdepan sampai ujung sirip ekor belakang dan panjang standard diukur dari bagian kepala terdepan sampai pelipatan pangkal sirip ekor (Effendie, 1992); (4) ikan-ikan dibedah untuk diperiksa isi perutnya; (5) tabulasi data; (6) dikonfirmasi melalui pustaka tentang relung makanan (feeding niche) setiap jenis ikan; (7) analisa data dan penulisan laporan.

\section{HASIL DAN PEMBAHASAN}

Jenis Ikan. Jenis ikan yang bermigrasi ke daerah mangrove pantai Tasik Ria Desa Mokupa pada saat air pasang ditunjukkan pada Tabel 1, terdiri dari delapan spesies yakni (1) Ikan Archamia fucata, (2) Lutjanus fulvus, (3) Lutjanus eherenbergii, (4) Lethrinus ornatus, (5) Scolopsis lineate, (6) Sargocentron diadema, (7) Epinephelus merra dan (8) Scorpaenopsis oxycephala. Jumlah ini tergolong kurang bila dibandingkan dengan yang dilaporkan oleh Suyoto et al (2019) dari studi di Daerah Perlindungan Laut, Sulawesi Utara, dengan menggunakan metoda sensus visual yakni sebanyak 93 jenis dari 25 famili. Hal ini tentu terkait dengan metode yang digunakan, misalnya penelitian ini menggunakan jaring insang yang berukuran $25 \mathrm{~m}$ panjang. Jaring yang panjang akan menutup areal yang lebih luas. Selain itu, di saat melakukan sampling tampak sejumlah nelayan sedang menebar jarring di lokasi yang sama, di sebelah ke arah laut. Kegiatan tersebut diduga ikut menghambat ikanikan masuk ke daerah mangrove dan mempengaruhi hasil tangkapan saat penelitian.

Tabel 1. Hasil tangkapan (individu) menurut waktu (pagi dan malam) dan panjang ikan (cm); T = Panjang Total dan S= Panjang Standar

\begin{tabular}{|c|c|c|c|c|c|}
\hline No & Jenis Ikan & Pagi & Malam & $\mathrm{T}(\mathrm{cm})$ & $\mathrm{S}(\mathrm{cm})$ \\
\hline 1 & Archamia fucata (Cantor, 1848) & 2 & 9 & 11,73 & 9.64 \\
\hline 2 & Lutjanus fulvus (Forster, 1801) & - & 3 & 12,23 & 9.90 \\
\hline 3 & Lutjanus eherenbergii (Peters, 1869) & 3 & 5 & 12,59 & 12.59 \\
\hline 4 & Letrinus ornatus Valencienne 1830 & - & 2 & 12,60 & 12.60 \\
\hline 5 & $\begin{array}{l}\text { Scolopsis lineata Quoy \& Gaimard, } \\
1824\end{array}$ & 2 & 15 & 12,95 & 12.95 \\
\hline 6 & $\begin{array}{l}\text { Sargocentron diadema (Lacepede, } \\
1802 \text { ) }\end{array}$ & 1 & - & 12,20 & 12.20 \\
\hline 7 & Epinephelus merra Bloch, 1793 & - & 2 & 12,20 & 12.20 \\
\hline 8 & $\begin{array}{l}\text { Scorpaenopsis oxycephala (Bleeker, } \\
1849 \text { ) }\end{array}$ & - & 1 & 12,20 & 12.20 \\
\hline
\end{tabular}




\begin{tabular}{|l|l|l|l|}
\hline Total & 8 & 37 & \\
\hline
\end{tabular}

Ikan Migrasi. Semua ikan tersebut di atas bukan penghuni tetap daerah mangrove, melainkan datang pada saat pasang dan kembali ke arah laut saat air mulai surut. Archamia fucata (Cantor, 1848) biasanya mendiami daerah terlindung, teluk dan daerah logoon di sekitar terumbu karang; hidup dalam kelompok besar di sekitar karang bercabang. Ikan ini bervarna-warni dan dijadikan ikan hias dan dipelihara di aquarium. Umumnya berukuran kecil atau kurang dari $10 \mathrm{~cm}$.

Lutjanus fulvus (Forster, 1801) dan Lutjanus eherenbergii (Peters, 1869) umumnya mendiami daerah rataan terumbu karang di sekitar lagoon hingga daerah luar terumbu; juvenilnya sering ditemukan di daerah dangkal sekitar Ikan Epinephelus merra (goropa, groupers) umumnya hidup di sekitar lagoon yang dangkal atau kedalaman kurang dari $20 \mathrm{~m}$, lebih menyukai pantai Ikan

Scorpaenopsis oxycephala (Bleeker, 1849) punya sirip punggung berduri dan berbisa, corak warna yang bervariasi, hidup di perairan dangkal sekitar $1 \mathrm{~m}$ hingga $35 \mathrm{~m}$. Ikan S.oxycephala bersifat soliter atau tidak membentuk kelompok dalam beraktivitas. Umumnya menempati daerah dasar yang berbatu atau sekitar terumbu karang (WoRMS, 2019). L. fulvus aktif makan pada malam hari (nocturnal) dengan makanan terdiri dari ikan-ikan, udang, kepiting, ketimun laut dan cephalopoda. $S$. diadema umumnya hidup di daerah mangrove bahkan daerah rawah sekitar muara yang terdapat aliran sungai. L.eherenbergii terkadang ditemukan dekat pinggir muara sungai dan ditanggap nelayan untuk dikonsumsi.

Ikan Lethrinus ornatus menyukai substrat dasar yang lunak sekitar daerah lamun pada pantai yang terlindung, biasanya terdiri dari beberapa individu dalam group, sering tertangkap nelayan dengan menggunakan jaring di sekitar pantai. Juvenil mengunjungi rataan terumbuh ketika air pasang. Ikan Scolopsis lineata hidup di sekitar lamun dasar berpasir hingga rataan terumbu, bergerak dalam group, juvenile biasanya berlindung di bawa karang dekat lagoon dengan air yang jernih.

agak terlindung (Heemstra dan Randall, 1993). Ikan jenis ini mulai dibudidayakan karena memilik nilai ekonomis penting.

subtidal, rataan terumbu, lagoon hingga kedalaman $30 \mathrm{~m}$.

Periode Migrasi \& Kategori makan. Ikan hasil tangkapan pada umumnya tergolong ikan-ikan yang melakukan migrasi pada sore/ malam hari, menurut jenis $88 \%$, menurut jumlah individu $82 \%$; dan jenis yang melakukan migrasi pada pagi dan malam hari sesuai irama pasang surut semidiurnal $\sim 50 \%$. Ikan-ikan tersebut ditunjukkan menurut kategori makan. Ikan-ikan hasil tangkapan (Tabel 2) hampir semuanya tergolong pemakan fauna lainnya (karnivor).

Tabel 2. Jenis ikan dan kategori makan

\begin{tabular}{|c|l|l|l|l|}
\hline No & Jenis Ikan & Famili & $\begin{array}{l}\text { Menurut } \\
\text { Pustaka }\end{array}$ & $\begin{array}{l}\text { Menurut } \\
\text { Pengamatan }\end{array}$ \\
\hline 1 & Archamia fucata & Apogonidae & Karnivora & $\begin{array}{l}\text { Moluska, udang, } \\
\text { Kepiting }\end{array}$ \\
\hline 2 & Lutjanus fulvus & Lutjanidae & Karnivora & Kepiting \\
\hline 3 & Lutjanuseherenbergii & Lutjanidae & Karnivora & Kepiting \\
\hline 4 & Letrinusornatus & Lethrinidae & Karnivora & Kepiting \\
\hline 5 & Scorpaenopsislineatus & $\begin{array}{l}\text { Nemipterida } \\
\text { e }\end{array}$ & Karnivora & Kepiting, udang \\
\hline
\end{tabular}




\begin{tabular}{|c|c|l|l|l|}
\hline 6 & Sargocentron diadema & $\begin{array}{l}\text { Holocentrid } \\
\text { ae }\end{array}$ & Omnivora & $\begin{array}{l}\text { pecahan karang, } \\
\text { siput,kepiting,udan } \\
\text { g }\end{array}$ \\
\hline 7 & Epinephelus merra & Serranidae & Karnivora & Molusca, kepiting \\
\hline 8 & $\begin{array}{c}\text { Scorpaenopsis } \\
\text { oxycephala }\end{array}$ & $\begin{array}{l}\text { Scorpaenid } \\
\text { ae }\end{array}$ & Karnivora & $\begin{array}{l}\text { Ikan kecil, } \\
\text { kepiting, } \\
\text { udang,molusca }\end{array}$ \\
\hline
\end{tabular}

Hasil kajian pustaka (antara lain Peristiwady 2006, Froese dan Pauly 2019) ikan Lethrinus ornatus memakanan krustasea, moluska, polychaeta dan ikanikan kecil. Ikan Scolopsis lineata makanan utamanya terdiri dari ikan-ikan kecil, krustasea dan pada umumnya polychaeta; ikan Sargocentron diadema mengkonsunsi polychaeta dan krustasea kecil; ikan Lutjanuseherenbergii pemakan ikan-ikan kecil. Ikan Epinephelus merra ketika masih juvenile mengkonsumsi krustasea dan ikan-ikan kecil; ketika menjadi dewasa tergolong piscivory atau pemakan ikan. Ikan Sargocentron diadema dikategorikan sebagai omnivore atau pemakan segala.

Faktor yang mempengaruhi makanan kebiasaan biota adalah (1) ketersediaan sumber daya sebagai bahan makanan (avalaibility), (2) aksesibilitas atau kemudahan untuk memperoleh bahan makanan, (3) kesedapan (palability) jenis sumber daya untuk dikonsumsi (Boneka 2013, 1994). Di daerah mangrove berasosiasi banyak biota avertebrata yang menjadi mangsa ikan-ikan predator. Hasil studi Boneka dan Laleleh (2010) menunjukkan ikan-ikan yang umum ditangkap nelayan di sekitar pantai mengkonsumsi group avertebrata, moluska, krustasea dan polychaeta yang merupakan komponan terbesar dalam usus dan lambung ikan. Pada umumnya, biota yang hidup di daerah pantai, periode makannya dipengaruhi oleh irama pasang surut, akuatik fauna bermigrasi pada saat pasang dan sebaliknya fauna terrestrial mencari makan di saat air surut (Boneka 2001).

\section{KESIMPULAN}

Ikan-ikan yang tertangkap dengan jarring insang di wilayah mangrove pantai Tasik Ria pada saat air pasang pada umumnya pemakan fauna lainnya atau karnivor, dan bersifat nocturnal, dengan ukuran panjang tubuh tergolong sedang.

\section{UCAPAN TERIMA KASIH}

Tulisan ini adalah bagian dari skripsi untuk Pendidikan sarjana (S1) di Prodi IImu Kelautan, Fakultas Perikanan dan IImu Kelautan, Universitas Sam Ratulangi

\section{DAFTAR PUSTAKA}

Boneka, F.B. 2013. Pengantar Ekologi Laut. Unsrat Press.

Boneka FB dan Laleleh S. 2010. Pengelompokkan ikan karang yang ditangkap nelayan lokal di sekitar TN Bunaken berdasarkan makanan kebiasaan. Ekoton 12 (1): 10-15.

Boneka, F.B. 2001. Feeding period of Littoraria scabra (Littorinide, Prosobranchia) on Bunaken Island, Indonesia.PMBC special Publication, 21(1): 269. ABSTRACT.

Boneka, F.B. 1994. Coexistance of Littoraria scabra dan L. pallescens (gastropoda: Littorinidae) in Northtern Sulawesi, Indonesia. PMBC Special Publication, 13: 147151.

Effendie, M. I. 1992. Biologi Perikanan. Yayasan Pustaka Nusatama. Yogyakarta.

Froese, R.dan D. Pauly. 2019. FishBase. Editors: World Wide Web electronic publication. version (02/2019). available online at http://www.fishbase.org . Dikunjungi 4 Juni 2019 
Gunarto, 2004. Konservasi Mangrove sebagai Pendukung Sumber Hayati Perikanan Pantai. Sulawesi Selatan : Balai Riset Perikanan Budidaya AirPayau.

Heemstra, P.C., dan J.E. Randall. 1993. Groupers of the World (Family Serranidae, Subfamily Epinephelinae): An Annotated and Illustrated Catalogue of the Grouper, Rockcod, Hind, Coral Grouper and Lyretail Species Known to Date. FAO Fisheries Synopsis, no. 125, vol. 16.382 hal.

Nikolsky, G. V. 1963. The Ecology of Fishes. Academic Press. New York.

Peristiwady,T. 2006. Ikan - Ikan Laut Ekonomis Penting Di Indonesia, Petunjuk Identifikasi.Lembaga IImu Pengetahuan Indonesia (LIPI). Jakarta, Indonesia.

Pramudji. 2008. Mangrove di Indonesia dan Upaya Pengelolaannya. Orasi Pengukuhan Profesor Riset Bidang Ekologi Laut. P2O-LIPI.31 hal.

Santoso, U. 2008. Hutan Mangrove, Permasalahan dan Solusinya. http ://uripsantoso.wordpress. c o m / 20 08 / 04 / 03 / h u t a n - mangrovepermasalahan-dan-

solusinya/?referer=sphere_related content/. Diakses 7 Juli 2009.

Schaduw, JNW. 2015. Keberlanjutan Pengelolaan Ekosistem Mangrove Pulau Mentehage, Wori, Sulawesi Utara. Jurnal LPPM, 2(2): 60-70.

Suyoto, T.S.H., Boneka, F.B,, Bataragoa, N.E., Ferse, SCA ${ }^{1}$, Lumingas, L.L., Lasut, M.L., Sumilat, D.A, dan Ngangi, E.L.A. 2019. Intensitas predasi pada ekosistem Mangrove di DPL Sulawesi Utara (in press).

WoRMS (worid dan F Rgister marine spesie ) 2019 Fish di kunjungi 2019 